Paediatrica Indonesiana 14: 1 - 10 Jan. - Feb. 1974

From the Department of Child Health, Medical School, University of Indonesia, Jakarta

\title{
Post-encephalitis Treatment with Encephabol
}

\author{
by \\ SUMARMO, SOFJAN ISMAEL, S.M. LUMBANTOBING \\ and SRI SUDARJATI NASAR
}

\section{Introduction}

The term encephalitis is nowadays still used by various writers for vague conditions of the brains without any inflammatory reaction. Some writers suggest to use the term encephalopathia.

The difficulty in establishing the etiological diagnosis of encephalitis has been stated by Lennette et al. $(1961,1962)$ who has not succeeded in determining the etiology of $45 \%$ $55 \%$ of his patients diagnosed clinically as encephalitis, whereas Sutedjo et al. (1961) has also failed in detecting the etiology of encephalitis in Indonesia.

The prognosis of encephalitis is very difficult to predict, severe clinical course could still improve without leaving any permanent sequelae.

In general the mortality is still high: Fiol's and De Francis' figure was $20 \%$ (1967), whereas Indonesian figures were respectively $35.6 \%$ Received Dec. 4, 1973.
(Ranti, 1961) and 38.7\% (Sutedjo et al. 1969).

Sequelae occur in the range of $20 \%-60 \%$ of the survivals (Horstmann, 1967; Sutedjo et al. 1969) and consist of psychiatric disorders (psychosis, disorder in behaviour, mental retardation, temper tantrums), as well as neurniogic disorders (paresis, epileptic parkinsonism, tics), obesity and blindness.

Encephabol, a drug produced by Merck in Darmstadt, West Germany, is a pyrithioxine and a derivative of pyridoxine (Vit. B6). The chemical formulas for pyridoxine and pyrithioxine are as follows:

Pyrithioxine is a bisulphide substitution of $2 \mathrm{CH}$-groups which are found in molecules of pyridoxine.

According to pharmacological trials pyritinol has the capacity to stimulate assimilation of glucose in the brains (Quadbeck et al., 1962). Encephabol is thus a cerebral neurotro- 


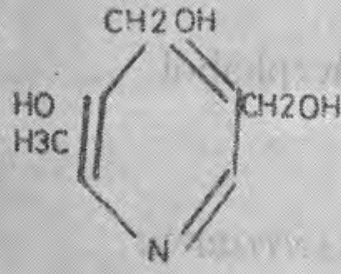

PYRIOOXINE

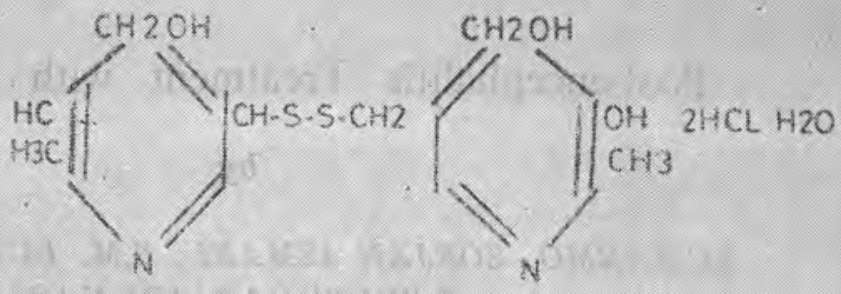

$\frac{\text { PYRITINOL-HCE }}{\text { (Encephobol) }}$ phic, it strengthens the dynamic effect of the central nervous system by increasing the brain cell metabolism.

Another pharmacological characteristic discovered by Hotovy et al. (1964), is that pyrithioxine has a certain specific action on the central nervous system by increasing the psychomotoric performance whilst circulation, respiration and visceral function are not or are almost not influenced.

On the central nervous system, this drug does not show any stimulating or depressive effects.

This medicine has been used in children suffering from craniocerebral trauma (Schreiber, 1965), from psychological and mental development disturbances (Hoffecker, 1964;
Ozek and Ozek, 1964; Khorana, 1969) ; in children with difficulties in learning, difficulties in speech and with slight mental retardation (Neu, 1965).

The purpose of this investigation is to evaluate the effect of encephabol as seen from the clinical, psychological and electroencephalographical points of view on patients suffering from post-encephalitis and also whether side effects may occur. For comparison and as a control vitamins of the B-complex group which are related to encephabol are given to some patienis.

\section{Material and methods}

The diagnosis of encephalitis was established on the following criteria: 
TABLE 1: Number of pa'ients given Encephabol and Vitamins.

\begin{tabular}{l|c|c|c|c}
\hline \multirow{2}{*}{ A g e - years } & \multicolumn{2}{|c|}{ Encephabol } & \multicolumn{2}{c}{ Vitamins } \\
\cline { 2 - 5 } & boys & girls & boys & girls \\
\hline $0-1$ & 1 & 1 & 2 & 1 \\
\hline $1-3$ & 1 & 4 & 1 & 3 \\
\hline $3-6$ & 1 & - & 2 & 3 \\
\hline 6 and older & 3 & 2 & 5 & 7 \\
\hline T o t a 1 & 6 & 7 & & \\
\hline
\end{tabular}

- Body temperature increases very quickly to a condition of hyperpyrexia.

- Lowering of consciousness.

- Long lasting convulsions.

- Neurological disorders which arise during the course of the disease.

- Liquor cerebrospinalis does not show any specificity except a slight increase in protein and the amount of cells.

The material consists of 25 patients who were discharged and considered clinically cured and followed up as post-encephalitis in the Department of Child Health, Dr. Cipto Mangunkusumo General Hospital, Jakarta, from August 1969 until August 1970. The ages ranged from 8 months to 12 years; there were 11 girls and 14 boys. Thirteen patients were given
Encephabol; the remaining 12 patients were given the following vitamins: B6, B1, E, Nicotinic acid (see Table 1).

The follow-up was carried out during a period of 6 months. Encephabo] and vitamins were given during 3 weeks, then withdrawn for 1 week. Clinical and neurological examinations were then carried out. E.E.G. was regularly made when the patient was discharged and repeated during the follow up. The apparatus used was of the Gross model D III having 8 channels. E.E.G. was performed during sleep. Psychological investigations were also carried out on discharge and repeated during this follow up.

The routine therapy consisted of:

- Anti convulsive drugs (phenobarbital, dilantin). 
TABLE 1 a : Dosage of Encephabol and Vitamins.

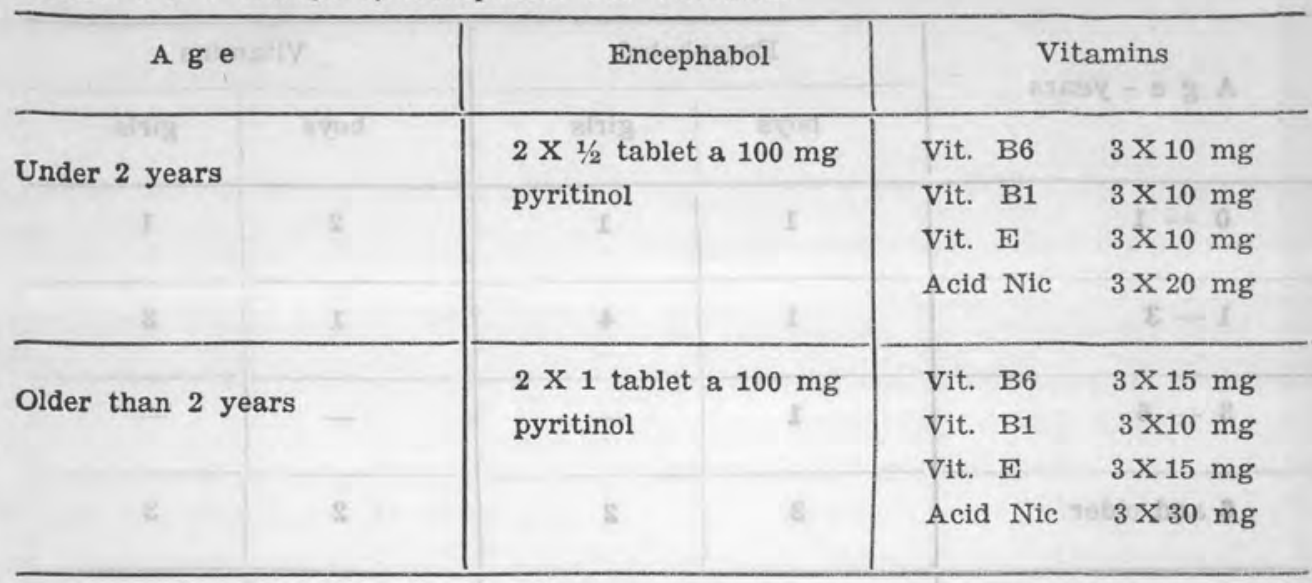

- To spastic hemiparetic tetraparetic conditions were given valium and physiotherapy.

- Encephabol next to the combination of Vit. B1, B6 and Vit. E and Acidum Nicotinicum (this was conventionally applied to postencephalitis patients) were orally given with dosages as follows (Table 1a) :
Probable toxic effects were evaluated by regular clinical observations and routine laboratory investigations of peripheral blood, urine and faeces.

\section{Result and discussion}

Twelve out of 13 patients treated with encephabol could be followed up during the entire 6 months, whereas out of 12 other patients treated with

TABLE 2: Follow up of patients for 6 months.

\begin{tabular}{|c|c|c|c|c|}
\hline 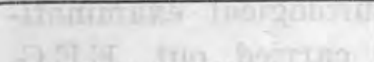 & Encep & bol & e tathigle Vita & nins 70 thpth \\
\hline A $\mathbf{g}$ e - years & girls & boys & girls & Woys \\
\hline $0-1$ & 1 & 1 & 1 & - \\
\hline $1-3$ & 1 & 4 & 10 & 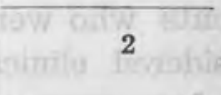 \\
\hline $3-6$ & 1 & -1 & 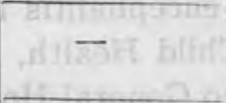 & -1 \\
\hline 6 and older & 2 & 2 & 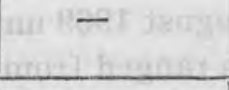 & A. \\
\hline$T \circ t$ & 5 & 7 & 2 & 2 \\
\hline
\end{tabular}


vitamins only 4 could be followed up during 6 months (table 2).

On discharge all patients had neurological residual symptoms; 2 patients had simultaneously 2 kinds of disorders, i. e. one had facial paresis with hemiparesis, the other facial paresis with tetraparesis.

After 6 months on encephabol a striking improvement occurred, i.e. neurological disorders disappeared in 10 cases. Facial paresis disappeared in the first month of treatment.

Hemiparesis in 2 patients disappeared in the first month and in another case in the 2nd month. Tetrapa- resis/paralysis disappeared in 2 patients in the first month, in another 2 patients in the 2nd month and in 1 case in the 3rd month of treatment.

The group on vitamins showed also a striking neurollogicall improvement, i.e. tetraparesis in 3 patients disappeared after 6 months of treatment, in 1 patient in the first month and in 2 patients in the 2nd month (Table 3).

Although the subjects in the 2 groups were different, one could not be sure whether encephabol is more favourable than vitamins.

TABLE 3 : Neurological disorders and follow-up.

\begin{tabular}{c|c|c|c|c}
\hline \multirow{2}{*}{ Neurological disorders } & \multicolumn{2}{|c|}{ Encephabol } & \multicolumn{2}{c}{ Vitamins } \\
\cline { 2 - 5 } & I & II & I & II \\
\hline N o r m a l & - & 10 & - & 3 \\
\hline Paresis N. Fascialis & 2 & - & - & - \\
\hline Hemiparesis & 5 & 2 & 1 & 1 \\
\hline Tetraparesis/paralysis & 7 & 2 & 3 & - \\
\hline T o t a 1 & 14 & 14 & 4 & 4 \\
\hline
\end{tabular}

I. Observation on discharge

II. Improvement after six months follow-up

Five out of 12 patients on encephabol showed a normal E.E.G. picture on discharge, whereas the remaining 7 patien's showed abnormalities, i.e. 2 borderline abnormal, 4 dis- function/inactivity and 1 showed 2 kinds of disorders simultaneously, dysfunction/inactivity next to focal iritation. 
Four out of 5 patients with nor- me worse, i.e. a focal irritation also mal E.E.G. retained a normal E.E.G. appeared (table 4).

but 1 developed an irritative focus Only one patient of the vitamins after 6 months of treatment. Out group showed improvement, i.e. from of 2 patients with borderline abnor- dysfunction/inactivity next to focal mal 1 had still the abnormality while irritation only the focal irritation the other became normal; out of remained. Although the number of 4 patients with dysfunction/inactivity subjects were small the opinion is abnormality, 3 still showed the previ- that there is no definite change in ous abnormality; the other one beca- the E.E.G. patterns of both groups.

TABLE 4 : E.E.G. pattern in follow-up.

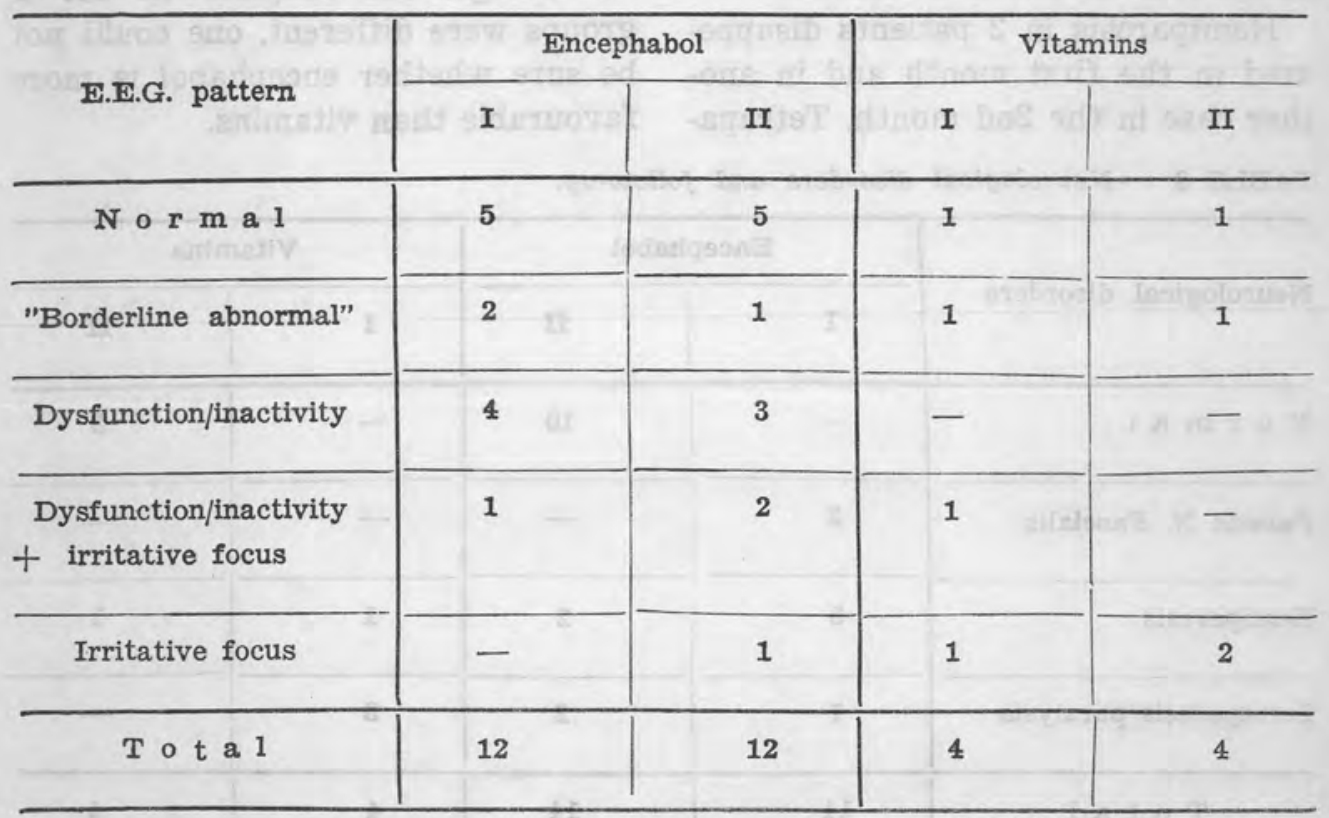

I. Observation on discharge

II. Change after six months treatment 
The psychological investigations were done by observing test apparatus and by obtaining supplementary information through anamnesis and observation. This investigation is aimed towards the intelligence level and the developmental stage of the subject. This developmental stage is classified according to social adaptation, mental and motoric development.

Due to lack of a reliable test apparatus, the conclusions concerning chilldren below 2 years of age depend mostly on observations by the parents, and test to evaluate more or less the degree of maturity in social and motoric aspects. Nonetheless, in our opinion there is a correlation between development of intelligence on one hand and of social and motoric maturity on the other hand.

In table 5 mental age (M.A.) is derived through the degrees of maturity in mental, social and motoric development. The determination of the degree of I.Q. is as follows:

\section{$\frac{\text { chronological age }}{\text { mental age }} \times 100$}

The patients treated with encephabol showed only a very slight improvement in their I.Q., i.e. 1 patient with a mental age bellow the chronological age achieved a normal average intelligence and another heavy moron patient became less moron.

Children treated with vitamins showed no improvement at all in their I.Q. We are aware that a period of 6 months is a very limited time to obtain accurate judgement on progress in the psychological field.

Khorana in India (1969) who carried out psychological investigations in 20 mentally retarded children on encephabol came to different conclusions. Four of his 20 patients were post-encephalitis patients. After 3 months of treatment 15 patients obtained an increase in their I.Q. varying from 5 to 15 even better results were achieved with the younger children.

Good result were also obtained by Nizar Zainal Abidin et al. (1970) in mentally retarded children at various extraordinary schools in Bandung after 3 months of treatmenit.

Their impression was:

1. In general encephabol gives good effects in mental function.

2. In general younger children with lower I.Q. are more responsive. 
TABLE 5: Observation on the degree of intelligence.

\begin{tabular}{l|c|c|c|c|c}
\hline \multirow{2}{*}{ Intelligence degree } & I. Q. & \multicolumn{2}{|c|}{ Encephabol } & \multicolumn{2}{|c}{ Vitamins } \\
\cline { 2 - 6 } & & I & II & I & II \\
\hline M.A. = C.A. (average) & $90-110$ & - & 1 & 1 & 1 \\
\hline "Borderline normal" & $70-80$ & 1 & 1 & - & - \\
\hline M.A. less than C.A. & & 3 & 2 & - & - \\
\hline Light moron & $60-70$ & - & 1 & - & - \\
\hline Heavy moron & $50-60$ & 5 & 4 & 1 & 1 \\
\hline Imbecile & less than & 3 & 3 & 2 & 2 \\
\hline Tot a l & 50 & 12 & 12 & 4 & 4 \\
\hline
\end{tabular}

M.A. = Mental age

C.A. = Chronological age
I. Observation on discharge

II. Evaluation after 6 months
During the encephabol treatment were encountered : 3 children became hyperactive, one child became more audacious and another child developed uncontrolled movements in the fourth month of treatment. Whether these symptoms could be categorized as side effects of the drug or as consequences of the post encephalitis condition itself, is difficult to define.

Persistent anorexia, nausea, decrease in body weight and becoming lazy as stated by other authors, however, were not found.
Other toxic effects were also absent.

\section{Conclusion}

A 6-month clinical evaluation on the effect of encephabol compared with the conventionally used combination of vitamins on post-encephalitic patients had been made in 25 children consisting of 11 girls and 14 boys, varying in age from 8 months to 12 years. It can be considered that encephabol might be used in the management of post encephalitis. 


\section{Acknowledgement}

The authors are very much indebted to the Division of Child Psychology, Faculty of Psychology, University of Indonesia, Jakarta, for the psychological evaluation; to E. Merck, Darmstadt/Germany and particularly to Merck representative in Indonesia, for the supply of sufficient amount of encephabol, enabling us to carry out this triail.

\section{REFERENCES}

1. FIOL, R.E. and DE FRANCIS, J.R. : Subacute sclerosing panencephalitis and measles encephalitis. Neurology part II, $18: 38$ (1967).

2. HOFFECKER, E.,: Observations with encephabol in paediatrics. Therapie der Gegenwart 103 : 913 (1964), quoted from Publications on encephabol, E. Merck AG-Darmstadt.

3. HORSTMANN, W. and HORAK, J. : Residuen nach Encephalitis im Kindesalter, Mschr. Kinderheilk. 115 : 282 (1967).

4. HOTAVY, R., ENENKEL, H.J., GILIISSEN, J., JAHN, U., KRAFT, H.G., MUELLER-CALGAN, H., MUERMANN, P., SOMMER, S. and STRUL. LER, R.: Pharmacology of vitamin Be and its derivatives. Arzneimittel forsch. $14: 26$ (1964) quoted from Publication on encephabol, E. Merck AG-Darmstadt.

5. KHORANA, A.B.: Phyrithioxine (encephabol) in the treatment of mental retardation. Indian. J. ment. Retard. 2: 108 (1969).

6. LENNETTE, E.H., MAGOFEI, R.L., LONGSHORE Jr., W.A., HOLLISTER Jr., A.C.: An etiologic study of seasonal aseptic meningoencephalitis in the Central Valley of California. Am. J. trop. med. Hyg., $10: 885$ (1961).
7. LENNETE, E.H., MAGOFFI, R.L, LONGSHORE Jr., W.A. and HOLLISTER Jr., A.C.: Viral Central Nervous Systems Disease. An etiologic study conducted at the Los Angelos Country General Hospital. J, amer. med. Ass. $179: 687$ (1962).

8. NEU, W.: Experiences with Encephabol in the paediatric practice. Landarzt, 41 : 523 (1965).

9. NIZAR ZAINAL ABIDIN, ISMAIL RACHMAT and H.H.B. SAANIN DT. TAN PARIAMAN: Beberapa pengalaman Psikiatrik mengenai pengobatan dengan Enchephabol terhadap anakanak terkebelakang di Bandung. Free Paper Workshop Perundang-undangan Kesehatan Djiwa Tahun 1970.

10. ÖZEK, S. and ÖZEK M. : Recent advances in the therapy of mental Deficiency. Abstracts, International Congress on the Scientific Study of Mental Retardation, Copenhagen : 68 (1964), quoted from Publications on Encephabol, E. Merck AG-Darmstadt.

11. QUADBECK, G., LANDMANN, H.R., SACHSSE, W. and SCHMIDT, I.: Der Einflusz von Pyrithioxin auf die BlutHirnschranke. Med. exp. 7:144 (1962). 
12. RANTI, I.S.F.: Neuroplegics in Encephalopathy. Paediatr. Indones. 1 : 158 (1961).

13. SCHREIBER, K.G.: Pyrithioxine in the treatment of Craniocerebral lesions. Landarzt, 41 : 1126 (1965).

14. SUTEDJO, MULJONO S. TRASTOTENOJO, and WIDHODHO: Pemeriksaan Etiologi encephalopathia (ence- phalitis) anak-anak dengan biopsi otak. Maj. Kedok. Indones. 12 : 135 (1961).

15. SUTEDJO, SOFJAN ISMAEL, RUSDI ISMAIL, SALEH MUHAMAD, RULINA SURADI dan SRI DARMAWAN: Pengobatan encephalitis anak dengan obat-tambahan Centrophenoxin (Helfergin). Maj. Kedok. Indon. 19: 11 (1969). 